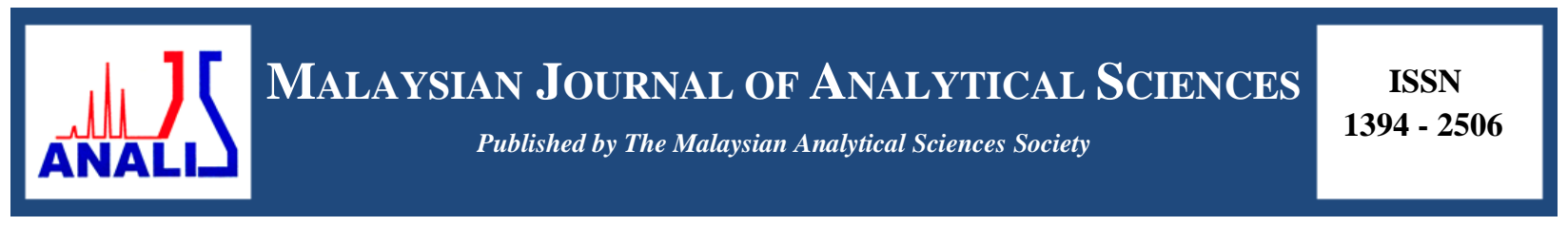

\title{
EFFECT OF Cu-PUROLITE A400 RESIN ON ADSORPTION OF NITRATE AND NITRITE IN WASTEWATER TREATMENT
}

\author{
(Kesan Resin Purolit A400-Cu Terhadap Penjerapan Nitrat dan Nitrit dalam Rawatan Air Sisa) \\ Fatimah Batubara ${ }^{1}$, Chairani Selviani ${ }^{1}$, Muhammad Turmuzi $^{1}$, Edy Herianto Majlan ${ }^{2,3 *}$ \\ ${ }^{1}$ Chemical Engineering Department, Faculty of Engineering, \\ Universitas Sumatera Utara, Medan, 20155 Sumatera Utara, Indonesia \\ ${ }^{2}$ Fuel Cell Institute, \\ Universiti Kebangsaan Malaysia, 43600 UKM Bangi, Selangor, Malaysia \\ ${ }^{3}$ Environmental Engineering Department, \\ Faculty of Environmental Engineering, \\ Institut Teknologi Yogyakarta, D.I Yogyakarta, 55171, Indonesia \\ *Corresponding author: edyhm71@gmail.com
}

Received: 13 April 2017; Accepted: 17 April 2018

\begin{abstract}
The exceedance of nitrate and nitrite concentrations over the water standard quality has caused potential human health dangers such as blue baby syndrome and the growth of aquatic plants (eutrophication). In this work, a Purolite A400 anion exchange resin impregnated by $\mathrm{Cu}$ (Purolite $\mathrm{A} 400-\mathrm{Cu}$ ) is used to remove nitrate and nitrite in wastewater. High saturation capacities of $0.76 \mathrm{mg} \mathrm{N} / \mathrm{g}$ and $0.88 \mathrm{mg} \mathrm{N} / \mathrm{g}$-nitrate and $0.10 \mathrm{mg} \mathrm{N} / \mathrm{g}$ and $0.11 \mathrm{mg} \mathrm{N} / \mathrm{g}$-nitrite are obtained from Purolite A400 and Purolite A400-Cu. Scanning electron microscope measurement shows that the surface of Purolite A400-Cu is rough due to other deposited materials that originate from $\mathrm{Cu}$ deposition. Energy dispersive spectroscopy measurement indicates that the increase in adsorption is due to $\mathrm{Cu}$ impregnation with the addition of a positive surface charge on the resin by $\mathrm{Cu}$. The adsorption capacities of nitrate and nitrite decrease with increases in sulphate, phosphate and chloride concentrations. Data are obtained from a fixedbed column using the Thomas equation model. The breakthrough curve shows the $\mathrm{C}_{\mathrm{t}} / \mathrm{C}_{0}$ ratio values in Purolite A400 and Purolite A400-Cu. Large $\mathrm{C}_{\mathrm{t}} / \mathrm{C}_{0}$ values of 0.55 and 0.52-nitrate and 0.48 and 0.03 -nitrite are obtained from Purolite A400 and Purolite A400-Cu.
\end{abstract}

Keywords: nitrite adsorption, nitrate adsorption, Purolite A400 resin, wastewater treatment, Cu impregnation

\begin{abstract}
Abstrak
Kepekatan nitrat dan nitrit yang melebihi piawaian kualiti air akan berpotensi membahayakan kesihatan manusia, sindrom birubayi dan pertumbuhan tumbuhan akuatik (eutrofikasi). Purolit A400 resin pertukaran anion yang impregnasi $\mathrm{Cu}$ (Purolite-Cu) digunakan untuk mengurangkan kandungan nitrat dan nitrit dalam air sisa. Kapasiti ketepuan tertinggi diperolehi pada Purolit dan Purolit-Cu masing-masing $0.76 \mathrm{mg} \mathrm{N} / \mathrm{g} ; 0.88 \mathrm{mg} \mathrm{N} / \mathrm{g}$-nitrat dan $0.10 \mathrm{mg} \mathrm{N} / \mathrm{g} ; 0.11 \mathrm{mg} \mathrm{N} / \mathrm{g}$-nitrit. Pengukuran dengan menggunakan spektrometri serakan tenaga (EDS) membuktikan bahawa peningkatan penjerapan adalah disebabkan oleh impregnasi $\mathrm{Cu}$ dengan penambahan caj permukaan positif pada resin oleh logam $\mathrm{Cu}$. Kapasiti penjerapan nitrat dan nitrit menurun apabila kepekatan sulfat, fosfat dan klorida bertambah. Data diperolehi daripada turus lapisan penjerap tetap menggunakan model persamaan Thomas. Lengkung bulus menunjukkan nilai nisbah $\mathrm{C}_{\mathrm{t}} / \mathrm{C}_{0}$ dalam Purolit dan Purolit-Cu. Nilai $\mathrm{Ct} / \mathrm{C}_{0}$ terbesar diperoleh pada Purolit dan Purolit-Cu masing-masing 0.55 \& 0.52-nitrat dan 0.48 \& 0.03 -nitrit.
\end{abstract}

Kata kunci: penjerapan nitrit, penjerapan nitrat, resin Purolit A400, rawatan air sisa, impregnasi $\mathrm{Cu}$ 


\section{Introduction}

Nitrogen is an essential element for all living things and can be oxidised to nitrate and nitrite. The content of nitrates and nitrites in water bodies significantly affects water quality. Nitrates are stable and water-soluble ions that have a low tendency of adsorption or co-precipitation [1]. Nitrate concentrations that exceed the water quality standard are caused using nitrate-containing fertilisers and human and animal wastes that are not pre-treated [2]. The consequences of nitrate contamination are potential human health hazards such as methemoglobinemia in infants (called blue baby syndrome) and crop growth (eutrophication) [3]. Therefore, nitrate and nitrite should be removed to enable the produced pollutant load to meet the determined minimum concentration standard.

The processing methods for nitrates and nitrites can be physical, chemical or biological. Physical techniques include reverse osmosis [4], ion exchange [5], catalyst reduction [6], electro-dialysis [7] and carbon activation [8]. Chemical methods include chemical denitrification [9]. Biological techniques include thermophilic nitrification-denitrification [10], ion exchange membrane bioreactor [11] and microbial denitrification [12]. A simple, cost effective and easily implemented adsorption method should be selected to achieve significant efficiency in the uptake of ions and remove secondary pollutants [13]. Adsorption through ion exchange is an efficient method of removing several oxyanions because adsorbents can be regenerated and reused [14]. The adsorbents, which are also natural resins, applied by the research institute, are modified zeolites with the addition of $\mathrm{H}_{2} \mathrm{SO}_{4}$ [15], amine group quartermodified chitosan beads [14] and alloy $\mathrm{Zr}(\mathrm{IV})$ with sugar beet pulp [16]. Synthetic resins used in nitrate and nitrite removal are strong base anion exchange resins with considerable adsorption capacity, such as ion-exchange resin Dowex 21K XLT with modified ferrous metals [17], Purolite A100 [18], Purolite A520E [19-20], A-250 IXR [21], Purolite A300 [20] and Indion NSSR [22].

Complementary ions, such as chloride, sulphate and phosphate, that are present in influent solutions can reduce the efficiency of nitrate and nitrite removal. The effect of complementary ions on nitrate and nitrite removal depends on their amount of charge. One-charged chloride ions do not affect removal efficiency, whereas sulphate ions with more than one charge significantly reduce removal efficiency. In previous studies that analysed the effects of complementary ions [20], an increase in the concentration of sulphate complementary ions on Purolite A300 resins decreased the nitrate removal efficiency in modified and unmodified resin types. According to [17], a low concentration of complementary phosphate ions reduces nitrate adsorption capacity, and complementary chloride ions slightly decrease nitrate adsorption capacity with same charge amounts of nitrate ions. Reference [23] indicated that the sequence of anion exchange resin decreases in the sequences of $\mathrm{SO}_{4}{ }^{2-}>\mathrm{NO}_{3}{ }^{-}>\mathrm{Cl}^{-}>\mathrm{HCO}_{3}{ }^{-}$.

A metal impregnation method is applied to increase the adsorption capacity of an anion exchange resin and enlarge the positive charge of the resin surface [24]. The impregnated resin increases the attraction between the positively charged metal ion and negatively charged nitrate and nitrite ions, thereby resulting in an increase in adsorption power. Reference [17] showed Fe impregnation in Dowex 21K XLT resin and obtained maximum nitrate adsorption capacities of 27.6 and $75.3 \mathrm{mg} \mathrm{N} / \mathrm{g}$ in Dowex and Dowex-Fe. Metal impregnation has also been conducted on resins and natural adsorbents, such as $\mathrm{Zr}(\mathrm{IV})$ in sugar beet pulp [16], Fe(III) in limestone [25] and $\mathrm{Mn}$ (II) in zeolites [26].

In this study, nitrate and nitrite removal was performed using a Purolite A400 resin adsorbent modified with copper $(\mathrm{Cu})$ metal. The nitrate and nitrite adsorption capacities were determined using Purolite A400 and Purolite A400-Cu in fixed-bed columns. The $\mathrm{C}_{\mathrm{t}} / \mathrm{C}_{0}$ ratio values were determined on the effect of the initial concentration of nitrate + nitrite mixture and the concentration of complementary ions in the Thomas equation model.

\section{Purolite A400 resin impregnation}

\section{Materials and Methods}

Purolite A400 resin is a strong base anion exchange resin that takes the form of faded yellow spherical beads with a particle size of $300-1200 \mu \mathrm{m}$ and a density of \pm 1.08 . The resin comprises a cross-linked polystyrene polymer structure with divinylbenzene and has a quaternary ammonium functional group of 1 . Purolite A400 resin was obtained from Purolite Pt. Ltd., Singapore. In this resin, the chloride ion is exchanged with another anion [27]. 
Purolite A400 resin was impregnated with $\mathrm{Cu}$ to enlarge its adsorption capacity. Purolite A400 resin $(10 \mathrm{~g})$ was mixed into $1 \mathrm{~L} \mathrm{CuCl}_{2} \cdot 2 \mathrm{H}_{2} \mathrm{O}$ solution and then stirred for 1 hour at $120 \mathrm{rpm}$. The $\mathrm{pH}$ was increased to 8.0 by adding a $1 \mathrm{M} \mathrm{NaOH}$ solution that was stirred for 1 hour at $30 \mathrm{rpm}$. The resin was filtered and washed with distilled water and then oven-dried for 24 hours at $\pm 45^{\circ} \mathrm{C}$ [17].

\section{Influent solution}

Synthetic wastewater was obtained from the crystalline powders of EMSURE $\mathrm{NaNO}_{3}$ and EMSURE $\mathrm{NaNO}_{2}$ dissolved with distilled water with 50 and $5 \mathrm{mg} / \mathrm{L}$ concentrations, respectively. The concentrations were 60, 90 and $150 \mathrm{mg} / \mathrm{l}$ or 1:1 for the study of the effect of the complementary ions obtained from the crystal powder of EMSURE $\mathrm{Na}_{2} \mathrm{SO}_{4}$, EMSURE $\mathrm{Na}_{3} \mathrm{PO}_{4}$ and EMSURE NaCl with determined concentrations for each complementary ion of 45 and $75 \mathrm{mg} / \mathrm{l}$ and for the study of the effect of the initial concentration of $\mathrm{NaNO}_{3}+\mathrm{NaNO}_{2}$ mixtures.

\section{Nitrate and nitrite analysis}

The final concentration $\left(\mathrm{C}_{\mathrm{t}}\right)$ of nitrate was analysed by a UV analyser Secomam RS232 Pastel tool [28], and the nitrite content was analysed by Cary 50 Conc UV-visible spectrophotometry-variant at a wavelength of $543 \mathrm{~nm}$ $[29,30]$.

\section{Fixed-bed column study}

The fixed-bed column used a chromatograph column made of Pyrex tube with a diameter of $\pm 2.0 \mathrm{~cm}$, height of \pm $20 \mathrm{~cm}$, anion resin height in a column of $15 \mathrm{~cm}$ and an influent rate to the column at $10 \mathrm{~mL} / \mathrm{min}$. The influent wastewater was pumped using a $12 \mathrm{~V}$ DC peristaltic pump with downflow through an infusion hose, I.V. needle 21 G x 11/2 and AC-DC adapter NAD-012 Namichi. The effluent wastewater samples were collected every 10 minutes, and the nitrate and nitrite contents were analysed using a UV analyser Secomam and a UV-visible spectrophotometer.

The adsorption capacities of removed nitrate and nitrite $(\mathrm{mg} \mathrm{N} / \mathrm{g}$ ) from the influent solution that passed through the column is expressed in q, and $\mathrm{q}_{\text {total }}$ (total of adsorbed nitrate) in the fixed-bed column is the area under the absorbed nitrate concentration curve $\mathrm{C}_{\mathrm{ad}}\left(\mathrm{C}_{\mathrm{ad}}=\mathrm{C}_{\mathrm{o}}-\mathrm{C}_{\mathrm{t}}\right)(\mathrm{mg} / \mathrm{l})$ against the effluent time (t, min) and calculated by equation 1 $[19,31]$.

$$
\mathrm{q}_{\text {total }}=\frac{\mathrm{Q}}{1.000} \int_{\mathrm{t}=0}^{\mathrm{t}=\text { total }} \mathrm{C}_{\text {ad }} \mathrm{dt}=\frac{\mathrm{Q}}{1.000} \int_{\mathrm{t}=0}^{\mathrm{t}=\text { total }}\left(\mathrm{C}_{0}-\mathrm{C}_{\mathrm{t}}\right) \mathrm{dt}
$$

The equilibrium adsorption capacity $(\mathrm{mg} \mathrm{N} / \mathrm{g})$ is calculated by equation 2 .

$$
\mathrm{q}_{\mathrm{eq}}=\frac{\mathrm{q}_{\text {total }}}{\mathrm{w}}
$$

where $\mathrm{w}$ is the mass of the adsorbent $(\mathrm{g})$ used in the fixed-bed column.

\section{Adsorption model}

The Thomas model used in the fixed-bed column is calculated by equation 3 as follows [32]:

$$
\ln \left[\left(\frac{\mathrm{C}_{\mathrm{o}}}{\mathrm{C}_{\mathrm{t}}}\right)-1\right]=\left(\frac{k_{\mathrm{Th}} q_{\mathrm{Q}} m}{\mathrm{Q}}\right)-\left(\frac{k_{\mathrm{rh}} q_{\mathrm{o}} \mathrm{V}_{\mathrm{eff}}}{\mathrm{Q}}\right)
$$

where $V_{\text {eff }}=$ volume of effluent and $V_{\text {eff }}=$ Q.t. Thus, equation 4 can be written as follows [19]:

$$
\ln \left[\left(\frac{\mathrm{C}_{\mathrm{o}}}{\mathrm{C}_{\mathrm{t}}}\right)-1\right]=\left(\frac{\mathrm{k}_{\mathrm{Th}} \mathrm{q}_{\mathrm{O}} \mathrm{m}}{\mathrm{Q}}\right)-\mathrm{k}_{\mathrm{Th}} \mathrm{C}_{0} \mathrm{t}
$$

where $\mathrm{k}_{\mathrm{Th}}=$ Thomas rate constant $(\mathrm{mL} / \mathrm{min} \mathrm{mg}), \mathrm{q}_{\mathrm{o}}=$ maximum solute concentration (nitrate) in solid phase (mg $\mathrm{N} / \mathrm{g}), \mathrm{m}=$ mass of adsorbent in column $(\mathrm{g}), \mathrm{Q}=$ volumetric flow rate $(\mathrm{mL} / \mathrm{min}), \mathrm{C}_{\mathrm{o}}=$ inlet nitrate concentration $(\mathrm{mg}$ 
$\mathrm{N} / \mathrm{L}), \mathrm{C}_{\mathrm{t}}=$ concentration of nitrate outlet at time $\mathrm{t}(\mathrm{mg} \mathrm{N} / \mathrm{L})$ and $\mathrm{t}=$ filtration time $(\mathrm{min}) . \mathrm{k}_{\mathrm{T}}$ and $\mathrm{q}_{\mathrm{o}}$ values are determined from the slope and intercept in the linear line plot, which is $\ln \left(\mathrm{C}_{0} / \mathrm{C}-1\right)$ against time $\mathrm{t}$.

\section{Characteristics of anion exchange resin}

\section{Results and Discussion}

The morphology and elemental composition of Purolite A400 and Purolite A400-Cu resins were analysed using a scanning electron microscope (SEM)-Jeol 6510-LA and an energy dispersive spectroscopy (EDS)-Jeol 6510-LA. The test results are shown in Figures 1 and 2. The surface of Purolite A400 resin is smooth, as shown in Figure 1a, whereas the surface of Purolite A400-Cu resin is rough, as shown in Figure 1b. This finding is due to the presence of other deposited materials on the surface that originated from $\mathrm{Cu}$ deposition. Furthermore, the surface of Purolite A400 resin impregnated with Purolite A400-Cu contains $\mathrm{Cu}$ ion. The concentration value of impregnated $\mathrm{Cu}$ ion impregnated is presented in Table 1. As shown in Figure 2, the content of $\mathrm{Cu}$ in Purolite A400-Cu resin is 19.34\%.
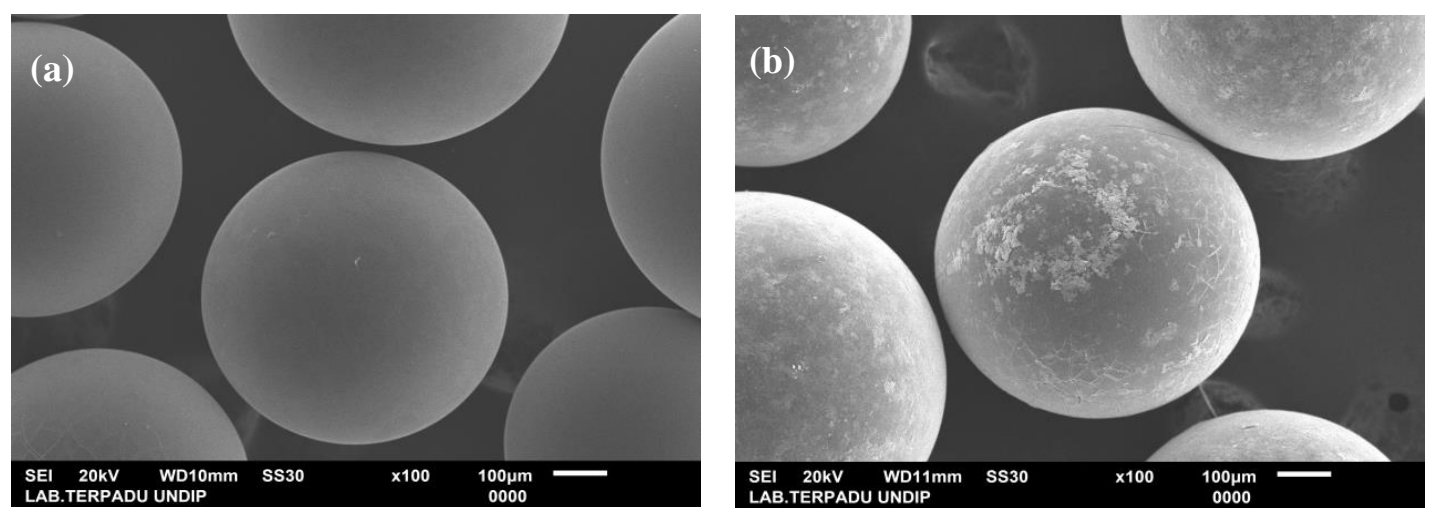

Figure 1. SEM test results (a) Purolite A400 resin and (b) Purolite A400-Cu resin (100x magnification)
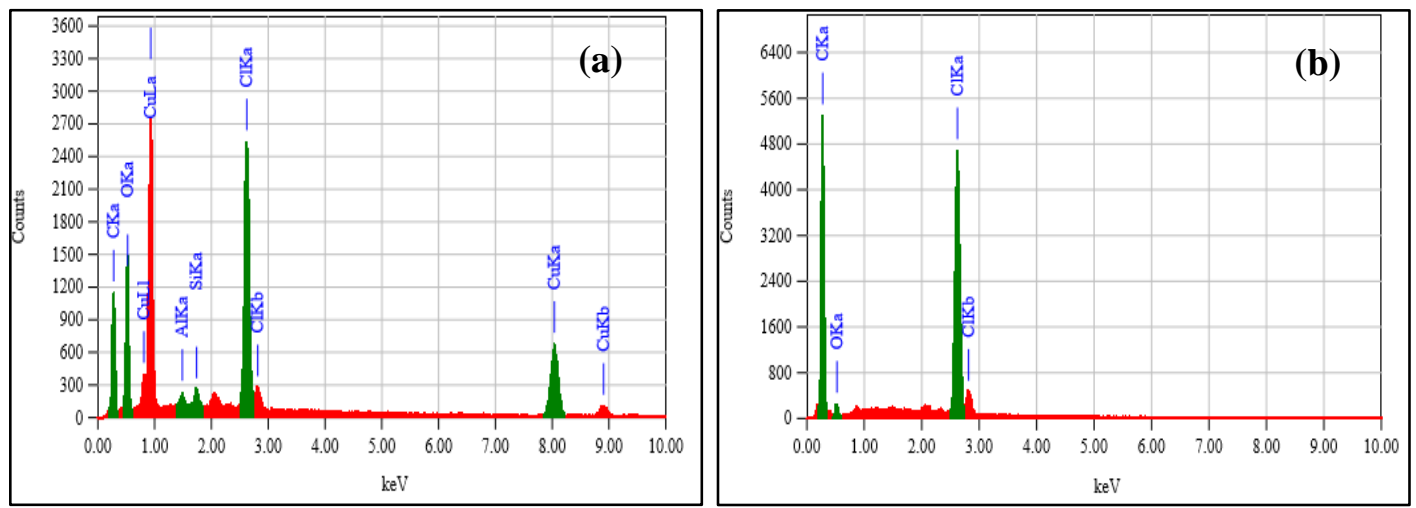

Figure 2. Results of EDS analysis (a) Purolite A400 Resin and (b) Purolite A400-Cu Resin

As shown in Table 1, $\mathrm{Cl}$ ion content in Purolite A400 resin also increases after impregnation from $7.98 \%$ to 9.67\%. The chloride ion $\left(\mathrm{Cl}^{-}\right)$in the resin is an interchangeable main anion [27]. 
Table 1. Composition of Purolite A400 and Purolite A400-Cu

\begin{tabular}{lcccccc}
\hline Adsorbent & $\begin{array}{c}\text { C } \\
\text { (wt.\%) }\end{array}$ & $\begin{array}{c}\text { O } \\
\text { (wt.\%) }\end{array}$ & $\begin{array}{c}\text { Cl } \\
\text { (wt.\%) }\end{array}$ & $\begin{array}{c}\text { Cu } \\
\text { (wt.\%) }\end{array}$ & $\begin{array}{c}\text { Al } \\
\text { (wt.\%) }\end{array}$ & $\begin{array}{c}\text { Si } \\
\text { (wt.\%) }\end{array}$ \\
\hline Purolite A400 & 86.64 & 5.38 & 7.98 & - & - & - \\
Purolite A400-Cu & 64.30 & 5.79 & 9.67 & 19.34 & 0.40 & 0.50 \\
\hline
\end{tabular}

\section{Adsorption capacity in fixed-bed columns}

The adsorption capacities of Purolite A400 and Purolite A400-Cu resins in nitrate and nitrite removal are shown in Tables 2 and 3. The adsorption capacities of nitrate with Purolite A400 and Purolite A400-Cu resins at the 1st test column of Table 2 are 13.49 and $17.58 \mathrm{mg} \mathrm{N} / \mathrm{g}$, respectively. The equilibrium capacities of nitrate with Purolite A400 and Purolite A400-Cu are 0.67 and $0.88 \mathrm{mg} \mathrm{N} / \mathrm{g}$, respectively. Similarly, the adsorption capacities of Purolite A400 and Purolite A400-Cu against nitrite at the 1st test column in Table 3 are 1.99 and $2.05 \mathrm{mg} \mathrm{N} / \mathrm{g}$, respectively. The equilibrium capacities are 0.099 and $0.102 \mathrm{mg} \mathrm{N} / \mathrm{g}$. The difference between the nitrate and nitrite adsorption capacities using Purolite A400 and Purolite A400-Cu are 4.09 and $0.05 \mathrm{mg} \mathrm{N} / \mathrm{g}$, respectively.

Table 2. Adsorption capacity of nitrate removal using Purolite A400 and Purolite A400-Cu

\begin{tabular}{|c|c|c|c|c|c|c|c|}
\hline \multirow[b]{2}{*}{ No. } & \multirow[b]{2}{*}{ Test } & \multicolumn{3}{|c|}{ Purolite A400 } & \multicolumn{3}{|c|}{ Purolite A400-Cu } \\
\hline & & $\begin{array}{c}\mathrm{C}_{\mathrm{t}} \\
\left(\mathrm{mgL}^{-1}\right)\end{array}$ & $\begin{array}{c}\mathbf{q}_{\text {total }} \\
(\mathrm{mg} \mathrm{N} / \mathrm{g})\end{array}$ & $\begin{array}{c}\mathbf{q}_{\mathrm{eq}} \\
(\mathrm{mg} \mathrm{N} / \mathrm{g})\end{array}$ & $\begin{array}{c}\mathrm{C}_{\mathrm{t}} \\
\left(\mathrm{mgL}^{-1}\right)\end{array}$ & $\begin{array}{c}\mathbf{q}_{\text {total }} \\
(\mathbf{m g ~ N} / \mathbf{g})\end{array}$ & $\begin{array}{c}\mathbf{q}_{\mathrm{eq}} \\
(\mathrm{mg} \mathrm{N} / \mathrm{g})\end{array}$ \\
\hline 1. & $\begin{array}{l}\text { Nitrate + Nitrite } \\
(60 \mathrm{mg} / \mathrm{L}) \\
\text { Chloride }(60 \mathrm{mg} / \mathrm{L}) \\
\text { Sulphate }(60 \mathrm{mg} / \mathrm{L}) \\
\text { Phosphate }(60 \mathrm{mg} / \mathrm{L})\end{array}$ & $\begin{array}{c}3.3 \\
4.2 \\
5.9 \\
10.8\end{array}$ & 13.49 & 0.67 & $\begin{array}{l}1.8 \\
1.9 \\
3.2 \\
3.3\end{array}$ & 17.58 & 0.88 \\
\hline 2. & $\begin{array}{l}\text { Nitrate }+ \text { Nitrite } \\
(75 \mathrm{mg} / \mathrm{L}) \\
\text { Chloride }(45 \mathrm{mg} / \mathrm{l}) \\
\text { Sulphate }(45 \mathrm{mg} / \mathrm{l}) \\
\text { Phosphate }(45 \mathrm{mg} / \mathrm{l})\end{array}$ & $\begin{array}{l}3.2 \\
3.5 \\
3.7 \\
9.3\end{array}$ & 14.35 & 0.72 & $\begin{array}{l}5.7 \\
5.9 \\
6.1 \\
6.3\end{array}$ & 15.95 & 0.80 \\
\hline 3. & $\begin{array}{l}\text { Nitrate + Nitrite } \\
(75 \mathrm{mg} / \mathrm{L}) \\
\text { Chloride }(75 \mathrm{mg} / \mathrm{L}) \\
\text { Sulphate }(75 \mathrm{mg} / \mathrm{L}) \\
\text { Phosphate }(75 \mathrm{mg} / \mathrm{L})\end{array}$ & $\begin{array}{c}1.8 \\
3.4 \\
4.4 \\
10.2\end{array}$ & 15.09 & 0.76 & $\begin{array}{c}2.7 \\
3.8 \\
4.0 \\
16.0\end{array}$ & 15.20 & 0.76 \\
\hline 4. & $\begin{array}{l}\text { Nitrate + Nitrite } \\
(90 \mathrm{mg} / \mathrm{L}) \\
\text { Chloride }(60 \mathrm{mg} / \mathrm{L}) \\
\text { Sulphate }(60 \mathrm{mg} / \mathrm{L}) \\
\text { Phosphate }(60 \mathrm{mg} / \mathrm{L})\end{array}$ & $\begin{array}{c}4.1 \\
6.6 \\
10.6 \\
11.8\end{array}$ & 13.55 & 0.68 & $\begin{array}{l}1.9 \\
2.0 \\
2.2 \\
3.5\end{array}$ & 17.59 & 0.88 \\
\hline 5. & $\begin{array}{l}\text { Nitrate + Nitrite } \\
(150 \mathrm{mg} / \mathrm{L}) \\
\text { Chloride }(60 \mathrm{mg} / \mathrm{L}) \\
\text { Sulphate }(60 \mathrm{mg} / \mathrm{L}) \\
\text { Phosphate }(60 \mathrm{mg} / \mathrm{L})\end{array}$ & $\begin{array}{l}1.9 \\
3.3 \\
4.2 \\
5.9\end{array}$ & 12.22 & 0.61 & $\begin{array}{l}3.0 \\
1.8 \\
1.9 \\
3.2\end{array}$ & 15.10 & 0.76 \\
\hline
\end{tabular}




\section{Batubara et al: EFFECT OF CU-PUROLITE A400 RESIN ON ADSORPTION OF NITRATE AND NITRITE IN WASTEWATER TREATMENT}

The nitrate adsorption capacity using Purolite A400 is $13.49 \mathrm{mg} \mathrm{N} / \mathrm{g}$ at the adsorption column volume (bed volume) of $9.24 \mathrm{BV}$. This finding is smaller than using Purolite $\mathrm{A} 400-\mathrm{Cu}$, which is $17.58 \mathrm{mg} \mathrm{N} / \mathrm{g}$ at the adsorption column volume (bed volume of) 10.19 BV. Similarly, the nitrite adsorption capacity using Purolite A400 resin with a bed column volume of $20.70 \mathrm{BV}$ is $1.99 \mathrm{mg} \mathrm{N} / \mathrm{g}$. This finding is smaller than using Purolite A400-Cu, which is $2.05 \mathrm{mg}$ $\mathrm{N} / \mathrm{g}$ resin at a bed volume of 18.31 BV. The bed volume values between Purolite A400 and Purolite A400-Cu does not have significant difference. Thus, the bed volume value is the same on Purolite A400.

Table 3. Adsorption capacity of nitrite removal using Purolite A400 and Purolite A400-Cu

\begin{tabular}{|c|c|c|c|c|c|c|c|}
\hline \multirow[t]{2}{*}{ No. } & \multirow[t]{2}{*}{ Test } & $\frac{\mathrm{C}_{\mathrm{t}}}{\left(\mathrm{mgL}^{-1}\right)}$ & $\frac{\mathbf{q}_{\text {total }}}{(\mathrm{mg} \mathrm{N} / \mathrm{g})}$ & $\frac{\mathrm{q}_{\mathrm{eq}}}{(\mathrm{mg} \mathrm{N} / \mathrm{g})}$ & $\frac{\mathrm{C}_{\mathrm{t}}}{\left(\mathrm{mgL}^{-1}\right)}$ & $\frac{\mathbf{q}_{\text {total }}}{(\mathrm{mg} \mathrm{N} / \mathrm{g})}$ & $\frac{\mathrm{q}_{\mathrm{eq}}}{(\mathrm{mg} \mathrm{N} / \mathrm{g})}$ \\
\hline & & \multicolumn{3}{|c|}{ Purolite A400 } & \multicolumn{3}{|c|}{ Purolite A400-Cu } \\
\hline 1. & $\begin{array}{l}\text { Nitrate + Nitrite } \\
(60 \mathrm{mg} / \mathrm{L}) \\
\text { Chloride }(60 \mathrm{mg} / \mathrm{L}) \\
\text { Sulphate }(60 \mathrm{mg} / \mathrm{L}) \\
\text { Phosphate }(60 \mathrm{mg} / \mathrm{L})\end{array}$ & $\begin{array}{l}0.040 \\
0.043 \\
0.049 \\
0.057\end{array}$ & 1.99 & 0.10 & $\begin{array}{l}0.006 \\
0.006 \\
0.459 \\
0.865\end{array}$ & 2.05 & 0.10 \\
\hline 2. & $\begin{array}{l}\text { Nitrate + Nitrite } \\
(75 \mathrm{mg} / \mathrm{L}) \\
\text { Chloride }(45 \mathrm{mg} / \mathrm{L}) \\
\text { Sulphate }(45 \mathrm{mg} / \mathrm{L}) \\
\text { Phosphate }(45 \mathrm{mg} / \mathrm{L})\end{array}$ & $\begin{array}{l}0.042 \\
0.056 \\
0.066 \\
0.126\end{array}$ & 1.99 & 0.10 & $\begin{array}{l}0.041 \\
0.047 \\
0.049 \\
0.055\end{array}$ & 2.18 & 0.11 \\
\hline 3. & $\begin{array}{l}\text { Nitrate + Nitrite } \\
(75 \mathrm{mg} / \mathrm{L}) \\
\text { Chloride }(75 \mathrm{mg} / \mathrm{L}) \\
\text { Sulphate }(75 \mathrm{mg} / \mathrm{L}) \\
\text { Phosphate }(75 \mathrm{mg} / \mathrm{L})\end{array}$ & $\begin{array}{l}0.030 \\
0.031 \\
0.036 \\
0.054\end{array}$ & 2.03 & 0.10 & $\begin{array}{l}0.006 \\
0.023 \\
0.064 \\
0.097\end{array}$ & 2.22 & 0.11 \\
\hline 4. & $\begin{array}{l}\text { Nitrate + Nitrite } \\
(90 \mathrm{mg} / \mathrm{L}) \\
\text { Chloride }(60 \mathrm{mg} / \mathrm{L}) \\
\text { Sulphate }(60 \mathrm{mg} / \mathrm{L}) \\
\text { Phosphate }(60 \mathrm{mg} / \mathrm{L})\end{array}$ & $\begin{array}{l}0.150 \\
0.784 \\
2.288 \\
3.226\end{array}$ & 1.27 & 0.06 & $\begin{array}{l}0.091 \\
0.396 \\
0.723 \\
3.214\end{array}$ & 1.57 & 0.08 \\
\hline 5. & $\begin{array}{l}\text { Nitrate + Nitrite } \\
(150 \mathrm{mg} / \mathrm{L}) \\
\text { Chloride }(60 \mathrm{mg} / \mathrm{L}) \\
\text { Sulphate }(60 \mathrm{mg} / \mathrm{L}) \\
\text { Phosphate }(60 \mathrm{mg} / \mathrm{L})\end{array}$ & $\begin{array}{l}0.036 \\
2.235 \\
2.869 \\
3.248\end{array}$ & 1.08 & 0.05 & $\begin{array}{l}0.052 \\
0.615 \\
1.581 \\
3.396\end{array}$ & 1.47 & 0.07 \\
\hline
\end{tabular}

\section{Breakthrough curve on nitrate removal}

The nitrate adsorption breakthrough curve using Purolite A400 and Purolite A400-Cu resins with influent nitrate concentrations of $50 \mathrm{mg} / \mathrm{L}$ is shown in Figures 3 and 4, respectively. The effect of complementary ion concentration influences adsorption capacity $\left(\mathrm{q}_{\mathrm{o}}\right)$ and Thomas $\left(\mathrm{k}_{\mathrm{Th}}\right)$ constant. The Thomas model uses a linear regression equation where $\ln \left(\mathrm{C}_{\mathrm{o}} / \mathrm{C}_{\mathrm{t}}-1\right)$ is the ordinate ( $\mathrm{x}$-axis) and time $(\mathrm{t})$ is the abscissa (x-axis). The $\ln \left(\mathrm{C}_{\mathrm{o}} / \mathrm{C}_{\mathrm{t}} 1\right)$ value plot of $\mathrm{t}$ represents a straight line with a linear equation as $y=a+b x$, where $a$ is the intercept that indicates the value of adsorption capacity $\left(\mathrm{q}_{\mathrm{o}}\right)$ and $\mathrm{b}$ is the slope that indicates the value of Thomas' constant $\left(\mathrm{k}_{\mathrm{Th}}\right)$. 
The model parameters for the fixed-bed columns using equation 4 are shown in Table 4 , where flow rate $\mathrm{Q}=10$ $\mathrm{ml} / \mathrm{min}$, influent nitrate concentration $\mathrm{C}_{\mathrm{o}}=50 \mathrm{mg} / \mathrm{l}$ and resin height $\mathrm{t}=15 \mathrm{~cm}$. As shown in Table 4 , the value of $\mathrm{k}_{\mathrm{Th}}$ increases with the increase of complementary ion concentration (chloride, sulphate and phosphate) and decreases when the initial concentration of nitrate + nitrite mixture increases in the nitrate removal using Purolite and Purolite$\mathrm{Cu}$. This finding shows the decrease in mass transfer rate due to the difference between the concentration of complementary ions in the resin and the concentrations of influent nitrate [33].

Table 4. Parameter of Thomas equation on nitrate removal

\begin{tabular}{lcccc}
\hline \multirow{2}{*}{ Test } & $\mathbf{k T}$ & $\mathbf{q}_{\mathbf{0}}$ & $\mathbf{k}_{\mathbf{T}}$ & $\mathbf{q}_{\mathbf{0}}$ \\
\cline { 2 - 6 } & \multicolumn{2}{c}{ Purolite } & \multicolumn{2}{c}{ Purolite-Cu } \\
\hline Nitrate + Nitrite $(60 \mathrm{mg} / \mathrm{L})$ & 0.044 & 3.199 & 0.024 & 3.578 \\
Chloride + Sulphate + Phosphate $(45 \mathrm{mg} / \mathrm{L})$ & 0.036 & 3.238 & 0.004 & 2.087 \\
Chloride + Sulphate + Phosphate $(75 \mathrm{mg} / \mathrm{L})$ & 0.060 & 3.915 & 0.063 & 3.735 \\
Nitrate + Nitrite $(90 \mathrm{mg} / \mathrm{L})$ & 0.042 & 2.769 & 0.020 & 3.527 \\
Nitrate + Nitrite $(150 \mathrm{mg} / \mathrm{L})$ & 0.098 & 4.132 & 0.062 & 3.389 \\
\hline
\end{tabular}

Each figure shows that the nitrate removal using Purolite A400 with an initial concentration of nitrate + nitrite mixture of $60 \mathrm{mg} / \mathrm{L}$ has a smaller $\mathrm{C}_{\mathrm{t}} / \mathrm{C}_{\mathrm{o}}$ ratio of 0.536 compared with concentrations of 90 and $150 \mathrm{mg} / \mathrm{L}$ of 0.549 and $0.543 \mathrm{mg} / \mathrm{L}$. For Purolite $\mathrm{A} 400-\mathrm{Cu}, \mathrm{C}_{\mathrm{t}} / \mathrm{C}_{\mathrm{o}}$ ratio of 0.52 was slightly smaller at the initial concentration of nitrate + nitrite mixture of $90 \mathrm{mg} / \mathrm{L}$ compared with the ration of 0.524 at $60 \mathrm{mg} / \mathrm{L}$ concentration. However, the value of $\mathrm{C}_{\mathrm{t}} / \mathrm{C}_{\mathrm{o}}$ ratio obtained was 0.564 at the initial concentration of nitrate + nitrite mixture of $150 \mathrm{mg} / \mathrm{L}$. For the effect of the concentration of chloride, sulphate and phosphate supplementation using Purolite $\mathrm{A} 400, \mathrm{Ct} / \mathrm{C}_{\mathrm{o}}$ ratio of 0.529 at $45 \mathrm{mg} / \mathrm{L}$ is smaller than the ratio of 0.536 at $75 \mathrm{mg} / \mathrm{L}$ concentration. Meanwhile, $\mathrm{C}_{\mathrm{t}} / \mathrm{C}_{\mathrm{o}}$ ratio of 0.506 at $45 \mathrm{mg} / \mathrm{L}$ was significantly lower than $\mathrm{C}_{\mathrm{t}} / \mathrm{C}_{\mathrm{o}}$ ratio of 0.556 at $75 \mathrm{mg} / \mathrm{L}$ concentration when using Purolite $\mathrm{A} 400$-Cu chloride, sulphate and phosphate. The value of $\mathrm{C}_{t} / \mathrm{C}_{\mathrm{o}}$ ratio affected final concentration $\left(\mathrm{C}_{\mathrm{t}}\right)$ and filtration time when the resin surface absorbed nitrate ions in the column

Figures 3 and 4 shows that the $C_{t} / C_{o}$ ratio of Purolite $A 400-C u$ is smaller than that of Purolite A400 without impregnation. This condition is because the time to reach saturation is longer because the active side of Purolite A400-Cu is larger, and more nitrate ions are adsorbed. According to Kalaruban et al. [17], the time to reach saturation is faster using Purolite A400 than Purolite A400-Cu because the number of active sides on Purolite A400 resin surface is less than Purolite A400-Cu when complementary ions exist in the influent solution. The resin is rapidly saturated when the concentration of chloride ions is added to a solution that contains nitrate ions, and the saturation level is achieved when the ratio value of effluent concentration to influent concentration $\left(\mathrm{C}_{t} / \mathrm{C}_{\mathrm{o}}\right)$ in the column is large [20].

The breakthrough curve characteristic is sharply increased in Purolite A400 and Purolite A400-Cu. The faster the saturation is achieved, the higher the $\mathrm{C}_{\mathrm{t}} / \mathrm{C}_{\mathrm{o}}$ ratio will be obtained. This condition occurs because the residence time in the column does not require considerable time to reach the adsorption equilibrium and the effluent nitrate solution leaves the column before the equilibrium is reached because the contact time between nitrate ions with Purolite A400 is short and the allowance efficiency decreases in saturation time [33]. 


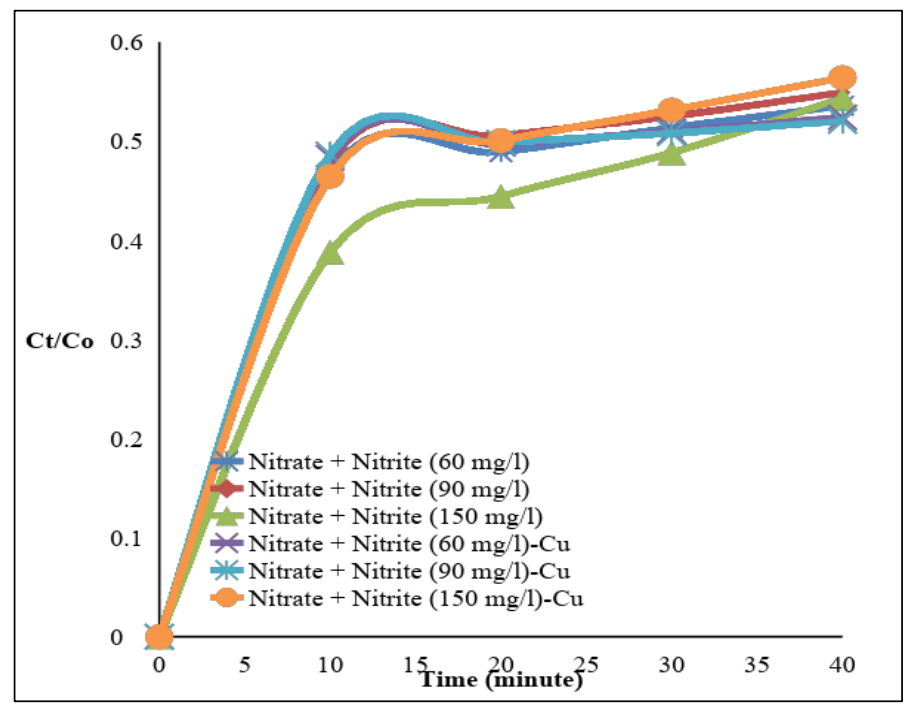

Figure 3. Breakthrough curve on nitrate removal based on the effect of initial concentration of nitrate and nitrite blends using Purolite A400 and Purolite A400-Cu

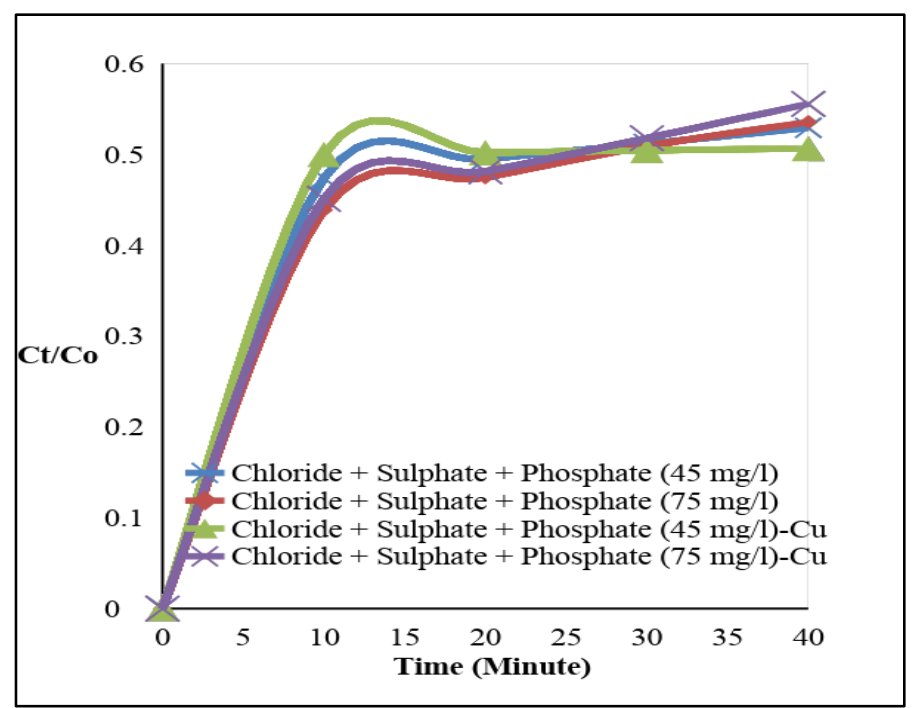

Figure 4. Breakthrough curve on nitrate removal based on the effect of compound ion concentration of chloride, sulphate and phosphate using Purolite A400 and Purolite A400-Cu

\section{Breakthrough curve on nitrite allowance}

Nitrite adsorption breakthrough curves using Purolite A400 and Purolite A400-Cu resins with influent nitrite concentrations of $5 \mathrm{mg} / \mathrm{L}$ are shown in Figures 5 and 6 , respectively. The model parameters for the fixed-bed column shown in Table 5 are expressed in equation 4 , where flow rate $\mathrm{Q}=10 \mathrm{~mL} / \mathrm{min}$, influent nitrite concentration $\mathrm{C}_{\mathrm{o}}=5 \mathrm{mg} / \mathrm{L}$ and resin height $\mathrm{t}=15 \mathrm{~cm}$. As shown in Table 3 , the value of $\mathrm{k}_{\mathrm{Th}}$ increases with the increase of complementary ion concentration (chloride, sulphate and phosphate) and reduces when the initial concentration of nitrate + nitrite mixture increases at the nitrite removal using Purolite A400-Cu. This condition shows the decrease in mass transfer rate due to the difference between the concentration of complementary ions in the resin and the concentrations of influent nitrate [33]. 


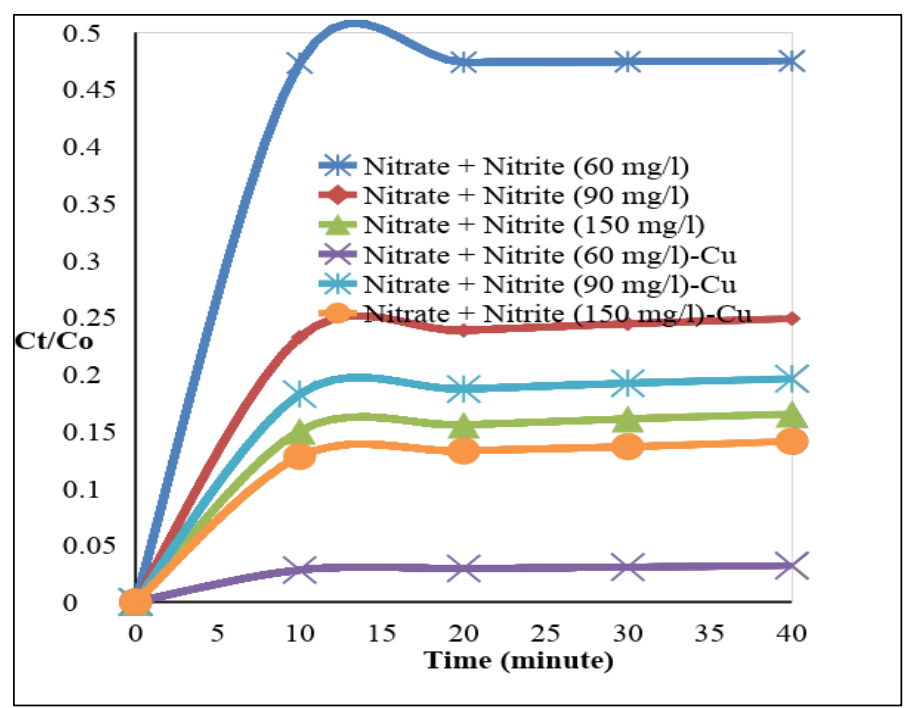

Figure 5. Breakthrough curve on nitrite removal based on the effect of initial concentration of nitric and nitrite blends using Purolite A400 and Purolite A400-Cu

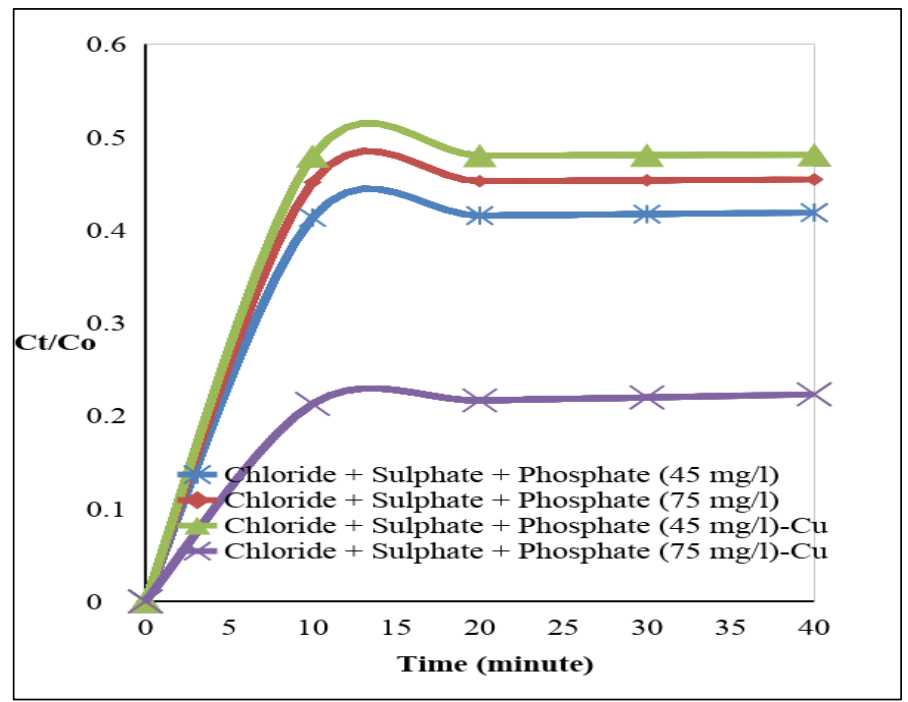

Figure 6. Breakthrough curve on nitrite removal based on the effect of compound ion concentration of chloride, sulphate and phosphate using Purolite A400 and Purolite A400-Cu

Each figure shows that nitrite removal using Purolite A400 with an initial concentration of nitrate + nitrite mixture of $60 \mathrm{mg} / \mathrm{L}$ has a greater $C_{t} / C_{o}$ ratio of 0.48 compared with the ratios of 0.25 and 0.17 at 90 and $150 \mathrm{mg} / \mathrm{L}$ concentrations. For Purolite $A 400-\mathrm{Cu}$, the $\mathrm{C}_{\mathrm{t}} / \mathrm{C}_{\mathrm{o}}$ ratio value at the initial concentration of nitrate + nitrite mixture 60 $\mathrm{mg} / \mathrm{L}$ was significantly smaller than the $\mathrm{C}_{\mathrm{t}} / \mathrm{C}_{\mathrm{o}}$ ratio of 0.03 . The value of $\mathrm{C}_{\mathrm{t}} / \mathrm{C}_{\mathrm{o}}$ ratio decreased to 0.20 at the initial concentration of nitrate + nitrite mixture of $90 \mathrm{mg} / \mathrm{L}$. Meanwhile, the value of $\mathrm{C}_{\mathrm{t}} / \mathrm{C}_{\mathrm{o}}$ ratio slightly decreased to 0.14 at the initial concentration of nitrate + nitrite mixture of $150 \mathrm{mg} / \mathrm{L}$. For the effect of the concentration of chloride, sulphate and phosphate ions using Purolite A400, a smaller $\mathrm{C}_{\mathrm{t}} / \mathrm{C}_{\mathrm{o}}$ ratio value was obtained at a concentration of 45 $\mathrm{mg} / \mathrm{L} 0.42$ compared with the ratio of 0.45 at $75 \mathrm{mg} / \mathrm{L}$ concentration. However, a large $\mathrm{C}_{\mathrm{t}} / \mathrm{C}_{\mathrm{o}}$ ratio of 0.48 was obtained at $45 \mathrm{mg} / \mathrm{mL}$ concentration of chloride, sulphate and phosphate when using Purolite A400-Cu. Meanwhile, the value of $C_{t} / C_{o}$ ratio was 0.22 at $75 \mathrm{mg} / \mathrm{L}$ concentration of chloride, sulphate and phosphate. The $C_{t} / C_{o}$ ratio 
value influenced final concentration $\left(\mathrm{C}_{\mathrm{t}}\right)$ and filtration time when the resin surface absorbed nitrite ions in the column.

Table 5. Parameter of Thomas Equation on nitrite removal

\begin{tabular}{|c|c|c|c|c|}
\hline \multirow{2}{*}{ Test } & $\mathbf{k}_{\mathbf{T}}$ & $\mathbf{q}_{0}$ & $\mathbf{k}_{\mathbf{T}}$ & $q_{0}$ \\
\hline & \multicolumn{2}{|c|}{ Purolite } & \multicolumn{2}{|c|}{ Purolite-Cu } \\
\hline Nitrate + Nitrite $(60 \mathrm{mg} / \mathrm{L})$ & 0.012 & 4.948 & 0.197 & 9.254 \\
\hline Chloride + Sulphate + Phosphate $(45 \mathrm{mg} / \mathrm{L})$ & 0.035 & 5.195 & 0.009 & 4.866 \\
\hline Chloride + Sulphate + Phosphate $(75 \mathrm{mg} / \mathrm{L})$ & 0.019 & 5.384 & 0.092 & 7.384 \\
\hline Nitrate + Nitrite $(90 \mathrm{mg} / \mathrm{L})$ & 0.137 & 4.614 & 0.143 & 5.505 \\
\hline Nitrate + Nitrite $(150 \mathrm{mg} / \mathrm{L})$ & 0.171 & 5.332 & 0.171 & 5.914 \\
\hline
\end{tabular}

Figures 5 and 6 show that the $C_{t} / C_{0}$ ratio using Purolite $A 400-C u$ is significantly small and the time to reach saturation is long because the active side of Purolite $\mathrm{A} 400-\mathrm{Cu}$ resin has many pores and the adsorbed nitrite ions are greater than Purolite A400. However, the $C_{t} / C_{o}$ ratio using Purolite A400 is smaller than Purolite A400-Cu for the influence of the $45 \mathrm{mg} / \mathrm{L}$ concentration of chloride, sulphate and phosphate 45 . This finding is inconsistent with existing theory on the role of $\mathrm{k}_{\mathrm{T}}$ and $\mathrm{q}_{\mathrm{o}}$ values in $\mathrm{C}_{\mathrm{t}} / \mathrm{C}_{\mathrm{o}}$ ratio. If the values of $\mathrm{k}_{\mathrm{T}}$ and $\mathrm{q}_{\mathrm{o}}$ using Purolite $\mathrm{A} 400-\mathrm{Cu}$ are relatively small, then the $C_{t} / C_{o}$ ratio value is greater than Purolite A400. The breakthrough curve sharply increases due to the influence of the initial concentration of the mixture of nitrate + nitrite $60 \mathrm{mg} / \mathrm{L}$ and the effect of complementary ion concentration chloride, sulphate and phosphate of $75 \mathrm{mg} / \mathrm{L}$. According to Li and Yang [23], breakthrough curves increased enormously because they dealt with complementary ion in the influent nitrite solution and mass transfer rate. A breakthrough point was achieved in a high influent concentration, and the increased concentration of influent adsorbate diminished the breakpoint time because the resin active site binding adsorbate rapidly saturated [32]. According to Babu and Gupta [33], the value of external mass transfer coefficient had a significant influence on the breakthrough curve. If the value of the external mass transfer coefficient is greater, the $C_{t} / C_{o}$ ratio value is not close to 1 (close to few constant values, value $<1$ and asymptotically constant after a certain time). The value of $C_{t} / C_{o}$ ratio asymptotically becomes constantly close to 1 when the value of external mass transfer coefficient is small.

\section{Conclusion}

Adsorption capacity was increased by modifying the adsorbent with metal impregnation that aimed at enlarging the surface positive charge. $\mathrm{Cu}$ content was obtained from Purolite A400 resin of 19.34\%, and the adsorption capacities of nitrate and nitrite removal using Purolite A400 and Purolite A400-Cu resin were 13.49 (nitrate) and $17.58 \mathrm{mg}$ $\mathrm{N} / \mathrm{g}$ (nitrate) and 1.99 (nitrite) and $2.05 \mathrm{mg} \mathrm{N} / \mathrm{g}$ (nitrite), respectively. The ratio of $\mathrm{C}_{\mathrm{t}} / \mathrm{C}_{0}$ to nitrate and nitrate removal using Purolite A400-Cu resin was small, and the saturation time was achieved with a long time because the active side of Purolite A400-Cu was large, and many nitrate and nitrite ions were adsorbed. The value of $\mathrm{C}_{\mathrm{t}} / \mathrm{C}_{0}$ in nitrate and nitrite removal was 0.506 at $45 \mathrm{mg} / \mathrm{L}$ concentration of chloride, sulphate and phosphate, and the value of $\mathrm{C}_{\mathrm{t}} / \mathrm{C}_{0}$ was 0.03 at the initial concentration of nitrate + nitrite $60 \mathrm{mg} / \mathrm{L}$ mixture ratio.

\section{Acknowledgement}

This work was supported by University of Sumatera Utara under the talented program. We thank to Integrated Laboratory in Semarang, Indonesia for the resin test analysis result of the research.

\section{References}

1. Rajeswari, M., Rajakumar, S. and Ayyasamy, P. M. (2015). Evaluation of nitrate removal in aquatic system: A general view. International Journal of Emerging Research in Management \& Technology, 9359 (12): 186 194.

2. Hanafi, H. A. and Azeema, S. M. A. (2016). Removal of nitrate and nitrite anions from wastewater using activated carbon derived from rice straw. Journal of Environmental \& Analytical Toxicology, 6 (1): 1-6. 
3. Chatterjee, S., Lee, D. S., Lee, M. W. and Woo, S. H. (2008). Nitrate removal from aqueous solutions by crosslinked chitosan beads conditioned with sodium bisulfate. Journal of Hazardous Materials, 166: 508 - 513.

4. Madaeni, S. S. and Koocheki, S. (2010). Influence of di-hydrogen phospate ion on performance of polyamide reverse osmosis membrane for nitrate and nitrite removal. Journal Porous Material, 17: 163 - 168.

5. Hekmatzadeh, A. A., Karimi-Jashani, A., Talebbeydokhti, N. and Klove, B. (2012). Modeling of nitrate removal for ion exchange resin in batch and fixed-bed experiments. Desalination, 284: $22-31$.

6. Guy, K. A., Xu, H., Yang, J. C., Werth, C. J. and Shapley, J. R. (2009). Catalytic nitrate and nitrite reduction with Pd - Cu/PVP colloids in water: composition, structure, and reactivity correlations. Journal Physical Chemistry, 113, $8177-8185$.

7. Bel, E. S., Hmida, H., Ouejhani, A., Lalleve, G., Fauvarque, J. F. and Dachraoui, M. (2013). A novel anionic electrodialysis membrane can be used to remove nitrate and nitrite from wastewater. Desalination and Water Treatment 23: $13-19$.

8. Khan, M. A., Ahn, Y. T., Kumar, M., Lee, W., Min, B., Kim, G., Cho, D. W., Park, W. B. and Jeon, B. H. (2011). Adsorption studies for the removal of nitrate using modified lignite granular activated carbon. Separation Science and Technology, 46: 2575 - 2584.

9. Sabzali, A., Gholami, M., Yazandbakhsh, A. R., Khodadadi, A., Musavi, B. and Mirzaee, R. (2006). Chemical denitrification of nitrate from groundwater via sulfamic acid and zinc metal. Journal Environmental Health Science Engineering, 3(3): $141-146$.

10. Lopez-Vazquez, C. M., Kubare, M., Saroj, D. P., Chikamba, C., Schwarz, J., Daims, H. and Brdjanovic, D. (2013). Thermophilic biological nitrogen removal in industrial wastewater treatment. Applied Microbiology Biotechnology, 98(2): 945 - 956.

11. Matos, C. T., Velizarov, S., Crespo, J. G. and Reis, M. A. M. (2006). Simultaneous removal of perchlorate and nitrate from drinking water using the ion exchange membrane bioreactor concept. Water Research, 40(2): 231 240.

12. Zhang, Y. and Angelidaki, I. (2012). Bioelectrode-based approach for enhancing nitrate and nitrite removal and electricity generation from eutrophic lakes. Water Research, 46(19): 6445-6453.

13. Hannachi, C., Guesmi, F., Fatma, K., Missaoui and Hamrouni, B. (2014). Application of adsorption models for fluoride, nitrate and sulfate ion removal by AMX membrane. International Journal of Technology, 5(1): 60 69.

14. Sowmya, A and Meenakshi, S. (2013). An efficient and regenerable quartenary amine modified chitosan beads for the removal of nitrate and phosphate anions. Journal of Environmental Chemical Engineering, 1(4): 906915.

15. Shaikh, I. I. and Chendake, Y. J. (2016). Removal of ammonium nitrate from aquaculture by sorption using zeolite. International Journal of Scientific Research in Chemistry, 1(1): $42-48$.

16. Hassan, M. L., Kassem, N. F and El-Kader, H. A. A. (2010). Novel Zr (IV)/sugar beet pulp composite for removal of sulfate and nitrate anion. Journal of Applied Polymer Science, 117(4): 2205 - 2212.

17. Kalaruban, M., Loganathan, P., Shim, W. G., Kandasamy, J., Naidu, G., Tien, V. N. and Vigneswaran, S. (2016). Removing nitrate from water using iron-modified Dowex 21K XLT ion exchange resin: Batch and fluidised-bed adsorption studies. Separation and Purification Technology, 158: $62-70$.

18. Bulgariu, L., Ceica, A., Lazar, L., Cretescu, I. and Balasanian, I. (2010). Equilibrium and kinetics study of nitrate removal from water by Purolite A100 resin. Revista de Chimie, 61(11): 1136 - 1141.

19. Nur, T., Shim, W. G., Loganathan, P., Vigneswaran S. and Kandasamy, J. (2014). Nitrate removal using Purolite A520E ion exchange resin: batch and fixed-bed column adsorption modelling. International Journal of Environmental Science and Technology, 12(4): 1311 - 1320.

20. Primo, O., Rivero, M. J., Urtiaga, A. M. and Ortiz, I. (2009). Nitrate removal from electro-oxidized landfill leachate by ion exchange. Journal of Hazardous Materials, 164(1): 389 - 393.

21. Li, W. B., Song, Y. B., Xu, H. K., Chen, L. Y., Dai, W. D. and Dong, M. (2015). Ion-exchange method in the collection of nitrate from freshwater ecosystem for nitrogen and oxygen isotope analysis: A review. Environmental Science Pollution Research, 22(13): 9575 - 9588.

22. Farajpourlar, M., Rao, S. R. M. and Rao, V. V. B. (2013). Studies on fixed and fluidized bed ion exchange column to treat wastewater. IOSR Journal of Environmental Science, Toxicology and Food Technology, 6(1): $1-6$. 
23. Li, H. and Yang, C. (2015). Nitrite removal using ion exchange resin: Batch vs. fixed bed performance. Separation Science and Technology, 50(11): 1721 - 1730.

24. Loganathan, P., Vigneswaran, S. and Kandasamy, J. (2013). Enhanced removal of nitrate from water using surface modification of adsorbents - A review. Journal of Environmental Management, 131:363 - 374.

25. Swarna, A. (2014). Removal of arsenic using iron coated limestone. Master Theses \& Specialist Projects. Western Kentucky University.

26. Zou, W., Han, R., Chen, Z., Jinghua, Z. and Shi, J. (2006). Kinetic study of adsorption of $\mathrm{Cu}(\mathrm{II})$ and $\mathrm{Pb}$ (II) from aqueous solutions using manganese oxide coated zeolite in batch mode. Colloids and Surfaces A: Physicochemistry Engineering Aspects, 279: 238 - 246.

27. Purolite (2017). Technical data ISO 9002. http://www.purolite.com. [Access online 7 September 2017].

28. Faiku, F and Haziri, A. (2016). Assesment of the water quality of Lumbardhi River, Prizren (Kosovo). Bulgarian Chemical Communications, 48(4): 646 - 658.

29. Zhang, J., Yang, C., Chen, C. and Yang, X. (2013). Determination of nitrite and glucose in water and human urine with light-up chromogenic response based on the expeditious oxidation of 3,3',5,5'-tetramethylbenzidine by peroxynitrous acid. Analyst, 138(8): $2398-2404$.

30. Roohparvar, R., Shamspur, T. and Mostafavi, A. (2016). Application of modified silica coated magnetite nanoparticles to separation-preconcentration and determination of nitrite. Chemical \& Metallurgical Engineering Journal, 4: 101 - 103.

31. Xu, X., Gao, B., Yue, Q., Li, Q. and Wang, Y. (2013). Nitrate adsorption by multiple biomaterial based resins: Application of pilot-scale and lab-scale products. Chemical Engineering Journal, 234: 397 - 405.

32. Chowdhury, Z. Z., Zain, S. M., Rashid, A. K., Rafique, R. F. and Khalid, K. (2013). Breakthrough curve analysis for column dynamics sorption of $\mathrm{Mn}(\mathrm{II})$ ions from wastewater by using Mangostana garcinia peelbased granular-activated carbon. Journal of Chemistry, 2013: $1-8$.

33. Babu, B. V. and Gupta, S. (2005). Modeling and simulation for dynamics of packed bed adsorption. Proceedings of International Symposium \& 57 Annual Session of IIChE in association with AIChE (CHEMCON-2004), Mumbai. 